\title{
Manuel Leguineche, últimas noticias de nuestro enviado especial
}

institucional.us.es/ambitos/

$26 / 10 / 2014$

\author{
Fermín Galindo Arranz \\ Universidad de Santiago de Compostela \\ fermin.galindo@usc.es
}

\section{Resumen}

Iba, buscaba la noticia y la reportaba. La idea es sencilla, pero forma parte de la dinámica periodística establecida por Manuel Leguineche. El hilo telefónico, el teletipo, la dificultad en las comunicaciones en tiempos de guerra, el periodismo de agencia, o la fuerza de lo inmediato ayudan a entender la vitalidad de sus crónicas, que han convertido al periodista y escritor en referencia obligada del enviado especial. La reciente pérdida de Manuel Leguineche, el 22 de enero de 2014, ha permitido a sus amigos y colegas completar con algunas anécdotas y nuevos apuntes biográficos el perfil de una figura literaria asociada siempre al mejor periodismo y al canon vital del corresponsal internacional.

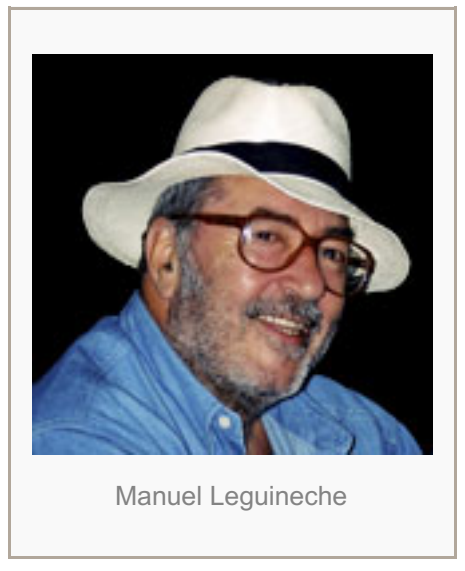

\begin{abstract}
He went there, he looked for news and he reported on it. The idea is simple, but it is part of the journalistic dynamic established by Manuel Leguineche. The telephone line, the teletype, the difficulties of communications in war times, the news agency journalism, or the strength of the immediate, help to understand the vitality of his chronicles, which have made of the journalist and writer an essential reference for special correspondents. Recent lost of Manuel Leguineche, on the 22nd January 2014, has enabled his friends and colleagues to complete with some anecdotes and new biographic notes the profile of a literary figure always associated with the best journalism and with the vital canon of this international correspondent.
\end{abstract}

\section{Keywords}

Special correspondent, news agency journalism, international correspondent, Leguineche, Delibes, Hemingway, New Journalism, Vietnam, La Tribu.

Iba, buscaba la noticia y la reportaba. La idea es sencilla, pero forma parte de la dinámica periodística establecida por Manuel Leguineche. El hilo telefónico, el teletipo, la dificultad en las comunicaciones en tiempos de guerra, el periodismo de agencia, o la fuerza de lo inmediato ayudan a entender la vitalidad de sus crónicas, que han convertido al periodista y escritor en referencia obligada del enviado especial. La reciente pérdida de Manuel Leguineche, el 22 de enero de 2014, ha permitido a sus amigos y colegas completar con algunas anécdotas y nuevos apuntes biográficos el perfil de una figura literaria asociada siempre al mejor periodismo y al canon vital del corresponsal internacional.

\section{La brújula de El Norte}

Manuel Ángel Leguineche Bollar nace en Belendiz-Arratzu (Bizkaia) el 28 de septiembre de 1941, poco después de la guerra civil. Inicia su trayectoria profesional de la mano de Luciano Rincón en el semanario Gran Vía de Bilbao en 1958, y dos años más tarde llega a El Norte de Castilla, cuyo director era Miguel Delibes. En 1960 comienza sus trabajos como enviado especial en acontecimientos internacionales. Como si de un teletipo más se tratara, Wikipedia despacha en unas escuetas líneas al escritor y periodista: "Destacado reportero, tuvo ocasión de presenciar y transmitir algunas de las crisis y conflictos bélicos más desgarradores del siglo XX. Fundó las agencias de noticias Colpisa, Cover, LID y Fax Press, y es autor de numerosos libros. Sus experiencias abarcaron desde la revolución de Argelia hasta la guerra entre India y Pakistán, la guerra de 
Vietnam, del Líbano, de Afganistán, de Marruecos, de Guinea Ecuatorial, las de los Balcanes o la primera guerra del Golfo. Los últimos años de su vida los pasó retirado en la localidad alcarreña de Brihuega, en Guadalajara". El 22 de enero de 2014 fallece a los 72 años a causa de una insuficiencia respiratoria en la Fundación Jiménez Díaz de Madrid. Sus cenizas reposan en el panteón familiar de Arratzu, en su Gernika natal.

Claude Bowers, embajador norteamericano en Madrid, dijo en 1954 que la Segunda Guerra Mundial empezó con el bombardeo de Gernika y a Manu Leguineche $(2001,226)$ le gustaba decir que "la Segunda Guerra Mundial había empezado en su pueblo", donde vino al mundo en 1941. Criado en la posguerra y en la autarquía de los cuarenta, cuenta Félix Maraña que Manu Leguineche, a finales de los cincuenta, se matricula en Derecho para evitar disgustos en casa. Allí, en la Universidad de Deusto, conoce al jesuita y escritor Bernardo de Arrizabalaga. Se hicieron amigos y compañeros de mus, y se fue con él a Valladolid, donde Beñat, como le llamaba Manu, iba a dirigir un colegio. Allí le presentó a Miguel Delibes, que dirigía El Norte de Castilla. "Vente mañana por el periódico, muchacho", le dice el autor de El camino. En la escuela y redacción de El Norte de Castilla se encuentra con Francisco Umbral, César Alonso de los Ríos, Javier Pérez Pellón, José Luis Martín Descalzo y el propio Arrizabalaga. Delibes lleva la dirección y forja su estilo y su cantera de escritores. Leguineche viaja a Londres, trabaja de camarero para aprender inglés, y a los 19 años se embarca en Alicante con destino, como corresponsal, a la guerra de Argelia.

Leguineche comienza trabajar como enviado especial para el diario Madrid y estudia en la Universidad Complutense. Leguineche $(1980,15)$ se aburre, estaba "hasta más arriba del gorro de aquella atmósfera opresiva de la universidad y de las tediosas clases de Filosofía y Letras, especialidad de Filología Italiana". En 1965 se une a un pequeño grupo de periodistas para dar la vuelta al mundo en la Trans World Record Expedition y, de paso, perder de vista a los grises, a los que había bautizado como "desertores del arado" demostrando ya un fino olfato para la crónica en el mismo campo de batalla. Todo esto lo contará en El camino más corto (1978), que se publica una década más tarde. Leguineche es uno más entre un grupo de periodistas tan todo terreno como los propios coches en los que viajaban. El camino más corto es un libro redondo, una vuelta de supervivencia a la tierra. Cuando todo el mundo miraba a la luna, ellos dan Una trepidante vuelta al mundo en automóvil. El volumen es la crónica vivida de un viaje de aventuras en el que, empezando como meritorio, Manuel Leguineche acompaña a tres periodistas norteamericanos: Harold Stevens, Albert Podell, Wood Stans, y al fotógrafo suizo Willy Mettler, con el propósito de batir el récord mundial de distancia recorrida en coche. El viaje, que iba a durar siete $u$ ocho meses, se prolongará durante dos años y más de 60.000 kilómetros.

A partir de entonces, el mundo se convierte en un territorio ya pateado para el de Gernika. Después de esta experiencia, cada vez que viaje como corresponsal contará con una referencia anterior. El enviado especial Manuel Leguineche $(1980,55)$ ya había estado allí. Cuando se publica el libro, más de una década después, su autor no duda en incorporar glosas personales sobre lo que sucedió posteriormente en muchos países de los que visitaron en la Trans World Record Expedition. "Volví a Argelia, años más tarde, en 1976, y también en 1979 una vez muerto Bumedian. Ben Bella vivía en residencia vigilada. La revolución de Bumedian estaba hecha con menos cantidad de palabras y más fábricas".

Antes de terminar el viaje, es reclamado como corresponsal internacionalen la guerra de Vietnam. Cuenta Leguineche $(1980,473)$ que había recibido, reexpedido desde Saigón, un telegrama en el que el diario Madrid le contrataba el envío desde el Vietnam de crónicas sobre la escalada militar norteamericana. Cuatro meses después $(1980,455)$, se encuentra sentado en una de las sillas de mimbre de la terraza del hotel de Graham Greene, el Continental de Saigón, bajo un ventilador de aspas, rodeado de limpiabotas, lisiados, peripatéticas, quiromantes y espías, frente a una cerveza Larue, cuando el botones del hotel, Nguyen Ti, entrega a Leguineche, un telegrama en bandeja de plata. Lo rasga con rapidez. Dice así: "Batido récord mundial Trans World. Stop. Llegamos Quinta Avenida. Nueva York. Stop. No encontramos sitio aparcar. Stop. Abrazos. Steve. Al".

Pasado el tiempo volvería a Saigón, esta vez en la primavera de 1975, cuando los blindados norvietnamitas avanzaban sobre el palacio presidencial. Desde entonces, enlaza una guerra con otra. Sabe, que su lugar está allí donde haya una guerra poscolonial que deba ser contada. Leguineche $(2001,222)$ aprende a eludir la censura militar en Saigón con Steinbeck, el Nobel de literatura, citando párrafos de la Guerra de las Galias, de 
Julio César. Tiene curiosidad por todo, estudia Literatura Francesa en Toulouse. Lee a los autores de referencia en cada país que visita, si puede en su propio idioma, e incluye las citas en sus reportajes. A los treinta años, después de haber dado la vuelta al mundo y de cubrir la guerra de Vietnam con la élite del periodismo mundial, después de estudiar derecho y filosofía se licencia en Ciencias de la Información por la UCM. No le da importancia: "a los que trabajábamos nos lo ponían más difícil".

Cuando se publica el libro, el autor ya es un periodista reconocido. Manuel Leguineche (1980: 475) mira por el retrovisor, agradece la enseñanza del oficio y reconoce la decisiva influencia de sus primeros compañeros de travesía: "Este libro debo dedicarlo a la memoria del compañero Willy Mettler, que cayó en la guerra de Camboya. De no haber sido por Willy yo no hubiera llegado a emprender la vuelta al mundo con la Trans World Record Expedition. Otros amigos, muy queridos, a los que debo agradecimiento porque me ayudaron entonces y ahora son, en primer lugar Miguel Delibes, Francisco Umbral, Bernardo Arrizabalaga, César Alonso de los Ríos, Mario Lacruz y Jesús Torbado, entre otros...". Cita también a sus parejas y a Rosa María Mateo que, "como dicen los novelistas y escritores anglosajones en sus dedicatorias, ha soportado con auténtica paciencia de Job la redacción de esta travesía de desiertos". El viaje más corto, como dice Enrique Clemente, "valía y vale aún pese a todo, más que mil manuales de periodismo para quienes pensaban en ser reporteros de internacional, corresponsales de guerra y viajar por el mundo".

En esta época, a finales de los sesenta, en una minúscula taberna de la calle Carretas y a partir de un pequeño despacho de EFE descubre junto a Jesús Torbado la existencia de un singular personaje. Un alcalde republicano reaparece en Mijas, Málaga. El edil del Frente Popular, Manuel Cortés, se había pasado encerrado treinta años en una habitación. Esperó hasta abril de 1969 para entregarse. La reacción de la prensa oficial fue ridiculizarle. Jesús Torbado y Manu Leguineche, en cambio, se pusieron a localizar otros casos por todo el país. Buscaron a espaldas de los archivos y de la guardia civil. Era gente que había estado escondida desde la guerra, hasta más de treinta años, por prudencia y por miedo. Les llamaron los topos. Manu y él tardaron cinco años en documentar un centenar de historias. Revolvieron la mitad del país en un Renault 8 con una enorme grabadora. Les solía acompañar Rosa María Mateo, la más guapa de las presentadoras de la televisión del momento, sobre todo a Manu.

Publicaron la vida de docena y media de ellos y de sus familias. La de aquéllos que sobrevivieron metidos en un armario, en una cuadra, en un doble techo, en un pozo, en una habitación ciega, y que un día decidieron hacerse topos para poder volver a ser hombres. Gregorio Morán recuperó la expresión de Arthur Miller mensaje en una botella cuando, tras leer la historia del alcalde republicano de Mijas, el de los 30 años escondido, escrita por el británico Ronald Fraser en 1972, dijo: "es como un mensaje intacto dentro de una botella, entre los despojos de la playa de la historia".

El editor Mario Lacruz les compró la historia y el libro Los topos vio la luz, nunca mejor dicho, en la editorial Argos Vergara en 1977. El éxito fue inmediato e intentó que ambos se convirtieran en un dúo parecido a Dominique Lapierre y Larry Collins, pero no fue posible. Leguineche se alistaba en todos los frentes y Torbado, que ya era premio Alfaguara, apostaba por la literatura. A partir de entonces no volvieron a escribir juntos, aunque siempre mantuvieron su amistad. Leguineche, no obstante, siguió con la costumbre de firmar libros en colaboración, llegando a participar en más de una docena de títulos.

En sus últimos años, Manu Leguineche (2002) encontró refugio en Brihuega, un paisaje con sustrato bélico que describe en Érase una vez en la Alcarria: "La guerra terminó y la represión cayó como una cuchilla. A veces te preguntas si la guerra civil, con su reguero de represalias y ajustes de cuentas, habrá terminado de verdad". La gran acogida de la película Los girasoles ciegos (2008), basada en el relato original de Alberto Méndez y con guion de Rafael Azcona y José Luis Cuerda, recuperó la actualidad de los topos, desconocidos para los más jóvenes. La editorial Capitán Swing decide entonces reeditar Los topos (2010), la investigación de Torbado y Leguineche que para Santi Segurola: "es un monumento a la decencia periodística. Tuvo que esperar siete años hasta la muerte de Franco para ser publicado. Un trabajo independiente, riguroso y pegado al suelo, que debe figurar en todas las escuelas y universidades españolas".

\section{El periodista de agencia}


Manu Leguineche dedicó su actividad periodística durante las tres últimas décadas del siglo XX a la dirección de agencias de noticias. Frente al imperio de la agencia estatal EFE, las agencias Colpisa, Cover, LID y FaxPress fueron una escuela alternativa al periodismo del momento. Durante doce años, entre 1970 y febrero de 1982, dirigió la agencia Colpisa de la que fue uno de sus fundadores. Entre los primeros colaboradores, están Paco Umbral y José Oneto, que escriben un artículo diario desde Madrid, uno literario y político el otro. Sus piezas se publican en un numeroso grupo de periódicos regionales que apuestan por la apertura en su línea editorial. El Norte de Castilla de Miguel Delibes, La Vanguardia de Horacio Sáenz, El Diario Vasco de Juan Mari Peña, El Correo Español de Antxon Barrena, El Diario de Navarra de Uranga, El Diario de Mallorca de Alemany o El Heraldo de Aragón de Brunet publicaban las crónicas que se enviaban desde Colpisa a diario. En 1981 se incorpora Maruja Torres, que escribe una columna para La Vanguardia.

Cuenta Pepe Oneto: "lo que no podíamos publicar en Madrid, lo publicábamos en provincias, a través de la Agencia Colpisa que fundó Manu para conservar su independencia, y la de un grupo de profesionales (este cronista venía del paro, después del cierre del diario Madrid por el Gobierno de Franco y su espectacular voladura) desde que empezamos estábamos convencidos de que aquel Régimen despótico tendría que cambiar, y que debíamos hacer todo lo posible, porque ese cambio fuera rápido y pacífico". De estos años, recuerda Mariano Guindal algunas de las crónicas que llevó a su director. "Aún me emociona cuando le puse sobre la mesa la matanza de los abogados laboralistas de Atocha, o el asesinato de Carrero Blanco: "aunque no te lo creas ha volado por los aires". Teníamos el instrumento para informar a la gente y que cada uno pudiera formar sus propias opiniones. Creíamos que la libertad de expresión era lo más importante, junto a la libertad de voto para nuestra sociedad. Vivíamos el periodismo como algo más que como una profesión, como una vocación en la que los scoop eran la sal del momento".

Mariano Guindal relata la extraordinaria velocidad a la que trabajaban, en una cadena tan escasa de medios como sobrada de entusiasmo. "Iba y reportaba la noticia al otro lado del hilo telefónico, Manu sentado al teletipo. ¡Un director haciendo de teletipista! Le contaba atropelladamente lo que estaba viendo y él picaba la cinta para no perder ni un segundo y ser los primeros en dar la información. Vivíamos el periodismo de calle contando historias y haciendo reportajes a cuatro manos". Los papeles cambiaban cuando había una guerra y era Leguineche el que iba de enviado especial. Entonces el resto de los redactores de la agencia eran los que tomaban nota para transcribir las crónicas recibidas.

Cuenta Pilar Cernuda que tenía una visión tan aguda que algunos compañeros llegaron a pensar que alguien divino le apuntaba dónde iba a haber un terremoto, un derrocamiento o un golpe de Estado. Había que estar de guardia si se iba por ahí un par de días a escribir o entrevistar a alguien: al poco empezaban a sonar las campanillas del teletipo para anunciar un acontecimiento precisamente donde se encontraba el jefe. El paso de la frontera siempre daba para una crónica: "Al cruzar ese mismo día por la frontera de Valencia de Alcántara tuve que despertar al guardián para que me abriera la barrera de paso. Un caso único: la revolución ardía en Portugal y el buen hombre, ajeno a todo, echaba la siesta". Otro clásico, como recuerda Guindal, era la conversación con el taxista que le llevaba del aeropuerto a la pensión más barata que había encontrado. Eso nos ponía en situación y a partir de ahí, era un torbellino. No había hora ni de la noche ni del día para descansar. "Espero que los que nos pagan el jornal nunca sepan que esto nos gusta tanto que lo haríamos gratis", bromeábamos mientras nos tomábamos unos vinos. De regreso de sus viajes nos reuníamos en su casa de Islas Filipinas hasta altas horas de la madrugada para que nos contara las historias que había vivido con la tribu de corresponsales. A las cinco de la mañana abría una lata de fabada Litoral y unas botellas de vino y volvíamos a cenar".

En marzo de 1982 funda la agencia Cover Prensa, que dirigiría hasta que en 1983 pasó a ser director general de la agencia LID (Línea Independiente de Diarios), puesto que desempeña hasta que en diciembre de 1990 Javier Godó, su mayor accionista, modifica el consejo de administración. Sus crónicas se publican en decenas de periódicos. LID es una agencia muy pequeña en la que todos tienen que hacer de todo. Belén Ayala recuerda que empezó en el periodismo en LID, como otros muchos, en un piso de la calle Zurbano en el que cada habitación era un cuarto de redacción, con algunas mesas y máquinas de escribir. Eran tiempos en los que los únicos ordenadores estaban en el despacho de las crónicas, donde los teletipistas picaban lo que acababas de escribir para enviarlo a los periódicos. 
En la década de los ochenta comienzan a fusionarse en grandes cadenas los periódicos y los directores procedentes de viejas familias dejan paso a jóvenes gestores. Poco a poco, se perdía una parte romántica del periodismo y de su esencia. Francisco Lussón explica cómo Leguineche vivía y sufría el imparable cambio corporativo de su primer cliente, los periódicos regionales. Sufría, y mucho -recuerda también Belén Ayala-, "parecía mentira que un tipo acostumbrado a desenvolverse en todas las situaciones imposibles que pueden vivirse en las guerras, y que había conocido los peores tugurios del mundo, se hiciera tan pequeño cuando tenía que negociar con los periódicos para que pusiesen una línea de su agencia. ¡Con lo grande que era! Porque Manu era muy grande. Su presencia física y su voz imponían. Allí aprendí a ser bombera, la especialización solo estaba permitida a los más veteranos, a Pilar, Berta, Kepa o Mariano. Los demás apagábamos el fuego donde surgían las llamas. Informaciones que se publicaban en el desaparecido Diario 16 y en toda la prensa regional. Costaba, pero de vez en cuando, de debajo de su enorme cuerpo asomaba el tipo afectuoso que, ya tarde, te hacía levantar de la silla y te llevaba a tomar vinos. No te pagaba un sueldo, pero te invitaba a cañas. En Los Morales, en la calle de Vallehermoso, en Madrid, con uno de sus enormes puros entre los dedos, surgía el interminable repertorio de anécdotas de tantos años de profesión, los chismes de los periodistas, y risas, muchas risas. Si esta locura de periodismo te gustaba ya un poquito, era imposible no enamorarse perdidamente de este oficio, sin horarios, entonces casi incompatible con cualquier tipo de vida privada".

En diciembre de 1990 crea un nuevo proyecto, la agencia Fax Press, que dirige durante una década hasta que fue adquirida por el Grupo Intereconomía en 2001. Enrique Portocarrero señala la premura en el envío de la crónica como la marca de la casa, en una época en la que transmitir la noticia era, a veces, tan difícil como sobrevivir en territorio comanche. El 17 de septiembre de 2009 cierra definitivamente Fax Press. La mayoría de sus redactores fueron a La Gaceta de los Negocios, cabecera del grupo y que, como tantas otras, tampoco ha superado la crisis.

Pilar Cernuda dirige la agencia después de Leguineche. "Somos muchos -afirma- los periodistas que lo somos porque Manu nos enseñó a serlo, multitud los privilegiados que hemos trabajado codo con codo con él, que hemos tenido la oportunidad de que nos contara cómo se contaba una historia y cómo se encontraba una buena fuente, que nunca era un portavoz oficial. Había que poner pasión en el estilo. Lo mejor era su espíritu, su pasión por el oficio, y cómo trasmitía esa pasión a los que trabajamos con él. Insistía siempre en que "el periodismo es contar historias".

Mariano Guindal es autor de El declive de los dioses. El libro es una extensa crónica de la transición económica española (1973-2011) narrada por un testigo directo de los acontecimientos. El relato parte siempre de la primicia informativa para ir revelando, con un ritmo eléctrico, lo que sucede a lo largo de estos años en los despachos más influyentes del país. Su autor, cuando habla de Leguineche usa la expresión "mi director" y dedica su libro: $(2011,5)$ “A Manu Leguineche, que me enseñó a amar profundamente esta profesión”.

Fernando Lussón fue redactor jefe en Fax Press y desvela cómo detrás del enviado especial a los grandes acontecimientos internacionales se esconde un periodista trotamundos que "busca los vuelos y los hoteles más baratos, sin apenas comodidades, y no aquéllos en los que se alojan los corresponsales de otros grandes medios. Sólo requiere que tengan teléfono y, a ser posible, en aquella época un fax". Busca no ser oneroso para sus periódicos. En este sentido el periodista y profesor de la USC Luis Álvarez Pousa nos cuenta cómo una noche, estando en Santiago de animada conversación con otros periodistas, prefiere quedarse a dormir en casa de los amigos que pernoctar en el hotel que ya tiene contratado. Pérez Reverte $(2012,66)$ cuenta que en Sarajevo, "a diferencia de los anglosajones que se alojaban en el Intercontinental, los españoles preferían el Explanade, más en la línea de los antiguos hoteles europeos, salvo Manu Leguineche, que se alojaba en el Internacional para ahorrar, porque siempre iba tieso".

Colabora también en el impulso de nuevas empresas periodísticas. Juan Mari Arregi reivindica cómo en 1977, cuando se lanza la campaña popular de suscripción de acciones de Egin y las aportaciones personales eran de 2.000 pesetas, Manu Leguineche envía el primer talón a la sede de Bizkaia por 25.000 de las antiguas rubias. "Fue la primera aportación individual fuerte, se alegraba de nuestra iniciativa y nos deseaba el mayor éxito". En otras ocasiones son los grupos editoriales quienes buscan su firma para apoyar sus nuevas publicaciones. Así, en 1987, Zeta llama a Leguineche para que participe en el lanzamiento de la revista Panorama, 
que,dirigida por Fermín Vilchez,trata de emular el estilo de otros semanarios europeos como París Match, Bunte o Quick. Su firma aparece junto a las de Mario Vargas Llosa, José Luis Sampedro, Lalo Azcona o Jorge Semprún.

Durante años, Manu forja una escuela de periodistas. Miguel Ángel Aguilar destaca que ayudó mucho a la gente joven. Es la otra cara de Manu, el creador de agencias de prensa para dar servicio a periódicos regionales: ejerce de maestro de los nuevos licenciados en las masificadas facultades de Ciencias de la Información. Cuenta Fernando Lusson que "en las agencias de prensa que Manu creó se curten muchos reporteros que conocen de su mano los rudimentos del oficio -rapidez, precisión, compromiso con la información- que ven en él un ejemplo". Con el tiempo han recordado su paso por aquéllas redacciones como una de las mejores etapas de su vida. "Con cuatro notas mal escritas era capaz de dictar una crónica memorable, verle trabajar en la máquina de escribir de su despacho, la puerta siempre abierta, un artículo con infinidad de referencias históricas, culturales, sociales sin mirar un solo papel porque todo lo guardaba en su cabeza. En ocasiones, sale de la redacción con un manojo de recortes de periódico en las manos y reparte a cada uno los suyos, acompañado de algún consejo sobre la vana vanidad y las recomendaciones que uno espera de un maestro: contrasta, confirma, duda, no seas cínico, sé medido. Bondadoso y generoso, siempre; gruñón, en ocasiones. Fuera de los focos, no presume de nada y menos de hazañas bélicas. Lo suyo era la gente, la humanidad".

Maruja Torres, que trabajó en Colpisa, explica que no se impone por su autoridad, sino por sus conocimientos y su sencillez. Leguineche se aplica a sí mismo, aunque no siempre con éxito, el saber del mus: "es costumbre horripilante chillar a tu ayudante". Así, cuenta Pilar Cernuda cómo en ocasiones rompía sus folios para que empezara de nuevo: "nunca sale nada bueno al escribir sobre un texto malo", y recuerda su entusiasmo cuando recibía su visto bueno. También Pilar Bernal cuenta cómo "los becarios de Fax-Press sumábamos temor y admiración a partes iguales hacia su imponente figura de reportero-jefe-hombre". Su despacho siempre era el mismo, una enorme trinchera llena de montañas de periódicos. Él mismo revisaba uno por uno los periódicos que se nutrían de las colaboraciones de la agencia. Gervasio Sánchez cuenta cómo conoció a Manu en Chile, durante el plebiscito contra Augusto Pinochet de 1988. Me acerqué a él, le llamé de usted y me presenté humildemente como un periodista que estaba empezando en el oficio. Él me contesto: "!Llámame Manu, coño!". También me dijo que leía mis textos en el Heraldo de Aragón. Me quedé con la boca abierta".

Su campo de batalla es la crónica en caliente, que sirve al momento, aderezada con la inmediatez de la conexión telefónica. Su capacidad de reflexión y una lectura inmediata de los acontecimientos aportan un estilo inconfundible a sus "leguineches", tal ycomo se conocían sus textos en las redacciones. Algunos, como Javier Fernández Barrera, recuerdan que "titulaba como un gran elefante cabrón, disparaba directo a los ojos del lector", y son capaces de reproducir de memoria algunas de sus crónicas. "A Frank Sinatra había que verle en su ambiente. No en Nueva York, ni en Los Ángeles, a las que tanto cantó. Había que conocerlo en Las Vegas, sobre las tablas, una hora antes de la actuación, con el escenario vacío, él sobre el piano, terco, profesional, concienzudo, sentado al piano, comprobando la última nota a la perfección, al límite, con su vaso de whisky con soda, girándola con un certero golpe de muñeca, bebiéndolo a sorbos con un cigarrillo entre los dedos. Ese era Frank Sinatra, el gran músico que hoy nos ha dejado".

Entre los muchos textos que se escribieron para glosar la desaparición de La Voz, para Barrera sólo uno merecía la pena, el "leguineche". "No es el texto original sino su recuerdo. Pero sí están las ideas que aprendí, la lección de Periodismo, porque ahí estaba todo. Estaba la noticia, estaba la diferencia respecto a los demás, el contexto, el conocimiento profundo del personaje y su explicación, la construcción de la imagen de que al tener que conocer a Sinatra en esa metáfora de hecho Leguineche nos lo estaba presentando. De pronto mi gaznate sabe whisky otra vez".

Otra curiosidad era la ininteligibilidad de sus originales. Cuenta Pilar Cernuda que enviaba sus textos "desde cualquier lugar del mundo por fax, a un espacio, y con seis o siete palabras juntas porque cobraban por palabra, y así engañaba a los funcionarios de correos de la India, Nicaragua, Bangladesh o Vietnam. Rehacerlas era un martirio". Koro Martínez, redactora de internacional de El Correo Gallego, recuerda cómo las crónicas de Fax Press eran tan buenas como de descuidada factura. En la mayoría de los diarios, las colaboraciones de Leguineche, siempre distintas, iban destacadas o directamente a primera. La última de todas ellas la dedicó a 
Lula, presidente de Brasil, el 25 agosto de 2005.

Sus libros, como sus crónicas, absorben la energía del directo y se acompañan de una documentadísima bibliografía. Basta leer la nota bibliografíca de Filipinas es mi jardín (1989, 271), con el que obtuvo el primer premio Reporter (1989) para reparar en su método de trabajo. "Había conocido a Imelda y Ferdinad en 1966 en Manila, al comienzo de una larga carrera presidencial que duró más de veinte años. Desde entonces seguí los pasos de la dictadura conyugal, reuní libros y biografías de las dispersas procedencias, hablé con amigos y enemigos..." Además, cita y comenta una numerosísima bibliografía internacional con decenas de títulos y no se olvida de reconocer a sus colegas, una auténtica foto de grupo de los corresponsales del momento: "Alfonso Rojo y Juan Carlos Algañaraz, enviados de Diario 16 a la crisis filipina, así como a Luis Goytisolo, a Elvira Santos corresponsal de $A B C$, a José Rodríguez de la agencia Efe, a Ramón Vilaró que fue un excelente corresponsal de El País, a Silvia de Béjar, Martín Domínguez y Joaquín Luna de La Vanguardia, a José V. Colchero y Luis Garmat, así como a Tico Medina que viajó para $A B C$ hasta los Tasaday. También quiero agradecer la ayuda y las informaciones de José Manuel Guerrero y Ángel Ibarlucea". El reportero no se olvida de ninguno y a todos reconoce su trabajo.

Con los años ha desarrollado un particular estilo que llega a todos los públicos. Alberto Ojeda explica que su secreto es que "Leguineche va por libre". El único director que tuvo fue Miguel Delibes, quien llegó a escribir: "no he conocido un periodista que en el breve plazo de unos años convirtiera sus viajes alrededor del mundo y alrededor de todas las guerras habidas y por haber en lecturas obligadas para el gremio de cabezas cultas y el de los apenas iniciados". Con estas mismas premisas, Guillermo Altares afirma que inventó un género propio: "escribió decenas de ensayos, en los que mezclaba la narración de viajes, el periodismo, la investigación y la historia. Con un estilo ágil, rápido, culto, divertido, inconfundible e inimitable. Desgraciadamente, muchos de sus libros están descatalogados, pese a las numerosas reediciones". Juan Cruz, en su faceta de editor, comenta cómo las portadas que le lleva para sus libros siempre le parecen bien y cómo asumía con deportividad que "las equivocaciones del editor muchas veces mejoran el original".

\section{El reportero de guerra}

La naturaleza viajera de Manu Leguineche y su pasión por relatar la novedad y lo vivido le hacen crecer como corresponsal de guerra. La de Vietnam le sitúa en primera línea de fuego. La objetividad del corresponsal y la veracidad de la información son fundamentales. Es un debate abierto y que se renueva en cada conflicto. "La guerra civil española es, junto con la de Vietnam, la que enfrentó al mundo en mayor medida desde lo que entonces podía entenderse por izquierda y derecha". Corresponsales de todos los periódicos trasladaron sus pasiones al papel. George Orwell señaló que "lo que decían los periódicos "no guardaba la menor relación con los hechos". Cuenta Leguineche $(2001,221)$ cómo en las trincheras españolas se inició un intenso debate entre objetividad y compromiso. Los corresponsales acreditados en el bando de la República fueron, por lo general, abanderados de la causa, lo mismo que los destacados en el bando franquista. Eran más los inclinados a tomar partido que los defensores de la vía descriptiva, distanciada, que contaba los hechos sin editorializarlos. "!A la mierda con la objetividad -gritó Martha Gellhorn-, aquí lo que está en juego es la derrota del fascismo!".

Este debate preocupa, y mucho, al periodista de Gernika. Manu Leguineche cita muchas veces la frase del senador norteamericano Hiram Johnson, que en 1917 en plena guerra mundial dijo: "The first casuality when war comes is truth" (Cuando llega una guerra, la primera baja es la verdad). Dedica un libro ("Yo pondré la guerra" (1998)) a la figura del magnate de la prensa W.R. Hearst, y en él se ocupa, sobre todo, de sus numerosas aportaciones al arte de manipular la opinión pública, especialmente cuando la Guerra de Cuba de 1898.

Leguineche $(2001,221)$ ve por primera vez a Ernest Hemingway en Pamplona, en la Plaza del Castillo, en 1959. Llegó a conocer personalmente al periodista americano en La Rioja, en concreto en Calahorra. Para él, Hemingway fue un gran escritor y un mal corresponsal. Cuando la República se derrumbaba en todos los frentes, Hemingway anunciaba en los periódicos canadienses su inminente victoria. "El corazón le pudo a la cabeza". En la retaguardia de las redacciones se libraba también una victoria sin fin. Las presiones conservadoras hicieron que The New York Times retirara de España a Herbert Mattews, que simpatizaba con la causa republicana y no lo ocultaba. Los sentimientos personales podían sobre la objetividad. Matthews 
reflexionó mucho sobre la ética y la deontología del corresponsal: "Todos los que vivimos la guerra española nos sentimos implicados apasionadamente en ella". Para Leguineche, es "el mismo y viejo error que lectores y directores seguirán cometiendo y que siempre acosará al cronista que, siendo humano, ha de tener opiniones propias".

En tiempo de guerra, propaganda e información viajan por los mismos canales y ocupan los mismos titulares. En este terreno, Manu es inflexible: el periodista debe dar testimonio objetivo de aquello que sucede. Los hechos son sagrados y los sentimientos del reportero quedan a un lado. Cuenta Leguineche $(2001,224)$ cómo un misionero español que encontró en Calcuta se había tomado la molestia de apuntar las cifras emitidas en los partes bélicos durante la guerra civil española, y cómo "al anunciar Franco en Burgos la derrota del Ejército Rojo, él sacó su cuaderno de notas y sumó los aviones derribados y los cañones destruidos durante tres años y descubrió que superaban con mucho la artillería y la aviación de todas las fuerzas armadas de Europa".

Escribe una novela, La Tribu (1981),sobre los enviados especiales en Guinea Ecuatorial durante la caída de Macías, de la que quedará la definición del grupo de nómadas que persiguen las noticias en primera línea y a los que agrupa bajo el paraguas de la triple $D$ : divorciados, deprimidos y dipsómanos. Dos décadas después, y ante la llamada de Leguineche, toda la tribu participa en Los ojos de la guerra (2001). Es un libro imprescindible, un homenaje a los periodistas Miguel Gil y Kurt Shork, muertos en Sierra Leona, y en el que participan con textos originales setenta corresponsales internacionales. Editado al alimón con Gervasio Sánchez, la visión final de la profesión y del devenir actual de las guerras es desoladora: "Hoy la guerra de Chechenia transcurre como lo hicieron las de principios de siglo: prohibiendo a los periodistas aproximarse a los frentes y dar testimonio objetivo de lo que en ellos sucede". $(2001,225)$.

La verdadera pasión de Leguineche consiste en contar historias en todos los formatos. Explica Félix Maraña que "quería ser periodista, como Hemingway, hablar inglés y "hacer" muchas guerras", y de este impulso inicial, animado además por un entorno favorable, arranca su vocación literaria y casi un nuevo género. Leguineche se sabe las novelas de Hemingway de memoria, "aprendí a leer con El viejo y el mar y con Adiós a las armas". Como él, economiza la prosa; es directo, claro, preciso. En Hotel Nirvana (1999) dedica dos capítulos a la ruta navarra de un Hemingway que encuentra en los Sanfermines, Irati, o Aralar sus lugares de peregrinación para la juerga y el descanso. "Un espacio vital para su filosofía hedonista, para su épica individual de héroe solitario". La emulación juvenil de los grandes corresponsales americanos, y una curiosidad innata impulsada por una atmósfera social asfixiante, empujan definitivamente la vocación viajera de Manu. Gracias a él, "el periodismo español dejó de ser paleto", dice Javier Reverte. Amigo íntimo de Manu, casi un hermano, desmitifica el asunto con humor. "Al periodismo de guerra le rodea una aureola gloriosa arriesgada, pero hay en el oficio algo de fantasmada y fantasía. Muchos periodistas intentan repetir en los campos de batalla el modelo de las películas y las novelas, lo que podría llamarse the Heming-way of life, construyendo sus relatos a partir de su propio protagonismo". Disfrutan, como Enrique Carretero con el sonido de las balas, "la que me va matar no la voy a oír". Y se disputan el título de la más puta entre las viejas zorras del oficio. La joven becaria de Fax Press, Pilar Bernal, acude a la presentación de una de las novelas de Arturo Pérez Reverte $(2012,43)$ sin conocer la jerga que se gastan. Queda aterrorizada por la dedicatoria del autor. "Un abrazo Manu, de parte de la puta más grande del periodismo español". Cuando entrega el libro a su jefe, monta en cólera, jserá cabrón, la puta más grande del periodismo español soy yo! Pilar escucha parapetada tras las torres de periódicos: "Oye, puta sí, pero con gusto, eh", y le deja una sonrisa para el recuerdo.

Javier Reverte $(2000,435)$ escribe en 1995, después de su experiencia en la guerra de los Balcanes, cómo "la gran mayoría de periodistas intentan informar lo mejor posible arriesgando lo menos posible. Algunos se juegan la vida -por obligación profesional algunos cámaras y fotógrafos, nunca los cronistas- y unos pocos tratan de montarse su propia aventura para ser recibidos como héroes a la vuelta. Estos últimos son malos periodistas. Los otros, los que suelen escribir más a menudo de las víctimas de la guerra que de las peligrosas batallas en que se ven envueltos, son los representantes de un noble oficio, por lo general mal pagado, y que provoca el nacimiento de numerosos escritores entristecidos por la muerte".

Muchos quisieron imitar a Hemingway y ahora son otros los que quieren emular a Leguineche. Iñaki Gabilondo $(2011,101)$ afirma que puede que aún existan figuras así, "porque el rastro de Manuel Leguineche es suficientemente atractivo para que otros se hayan lanzado en tromba a seguir una actividad vivida con gran 
nobleza, esto es, tratando de ser un relator sin caer en los personalismos. En su caso el protagonismo es el que inexorablemente le ha correspondido dada la naturaleza de las historias que contaba, nunca porque él haya trabajado para imponerse como protagonista". El reportero Alfonso Rojo así lo reconoce, y corrobora su humildad frente al foco de atención: "no era envidioso ni protagonista, buen compañero y bueno en su trabajo, tal vez en eso influía el que trabajara en una agencia". El 30 de marzo de 2014, cuando liberan al periodista Javier Espinosa, secuestrado en Sierra Leona el 16 de septiembre de 2013, el despacho de EFE dice de él que es: "el más aventajado reportero en la estela de Manu Leguineche".

Arturo Pérez Reverte no dudó en situar al personaje, en su novela Territorio Comanche (1994, 61), "tecleando su Olivetti en la terraza del hotel Continental, con el Vietcong a tiro de piedra",y cuenta una anécdota en la que retrata al amigo. "En 1982, en la guerra entre Israel y el Líbano, le dije que iba a ir al frente, a Beirut, y que nos veríamos al día siguiente. El reportaje me quedó bastante bien con fotos de los tanques israelíes por las calles de la capital libanesa. El material era tan bueno que decidí coger un avión y llevarlo personalmente a Madrid y luego regresar. Pero no se lo dije a Manu, que pensó que había desaparecido. Estuvo por los hospitales preguntando si había allí un sahafi espani, un español al que hubieran dado matarile. Era tan buena persona que pasó dos días buscándome hasta que regresé. Era muy buen compañero". Visto lo visto, el juicio de Pérez Reverte, es taxativo: "antes de Manu el periodismo de guerra era una cosa folclórica. Con él se vuelve algo serio y alcanza la mayoría de edad. Con él se transforma la figura del corresponsal de guerra para dotarla de respeto y profesionalidad. Encontrarle en un hotel siempre era una alegría y una garantía de que todo iría bien". Sumaba, por tanto, la categoría de talismán a la de veterano periodista.

En 1995 dirige para TVE la serie documental Memoria de la Guerra, sobre la I/ Guerra Mundial. Javier Muñoz entrevista a Leguineche en esos días. Aun siendo un principiante, le da un trato exquisito y algunas de las claves de su trabajo. Le cuenta que, tras la caída del Sha, un periodista francés le dijo en un hotel de Teherán "Oye, vámonos de aquí, que ya hemos visto lo mejor, y ahora que vengan los analistas".

\section{Una mirada crítica y compasiva}

La elección del punto de vista desde el lado más débil siempre ha sido marca de la casa. Ya en 1965, en su primer libro y desde las antípodas, Leguineche $(1980,469)$ toma partido por los aborígenes australianos: "Ahí los tenéis, como en la Edad de Piedra. El primitivismo está de moda y todo el mundo trata de chupar su sangre. ¡Pobres abos, destruidos como los comanches, los sioux, los navajos...! Los aborígenes son ciudadanos de segunda. Después de que aniquilaran su caza, como les sucedió a los indios de América con sus búfalos y bisontes, se les prohibió la compra de bebidas alcohólicas y, lo que es más significativo, no figuran en el censo y no se les permite votar a pesar de que su número, sesenta u ochenta mil, no debería preocupar a los profesionales de la política, celosos de sus alianzas y de sus estadísticas favorables. Menos mal que hoy no están solos y hay quienes luchan por sus derechos y por su integración". Aunque Leguineche $(2001,12)$ señala cómo fue en Vietnam donde se inauguró una" visión compasiva y crítica de la guerra".

De forma natural asume como propio un compromiso ético con la verdad, y entiende el periodismo como la denuncia de cualquier abuso del poder establecido. Enemigo del envaramiento, busca sus héroes entre las gentes anónimas. Como algunos de sus amigos misioneros, practica cierta "deonteología de la liberación" periodística. Manu Leguineche tiene una certeza: "todas las guerras se pierden" y quien ha perdido todas merece su máximo respeto. Así, la biografía de Antonio García Barón merece del reportero un relato pormenorizado. Busca al protagonista en la selva del Amazonas para que le cuente su vida en primera persona. Cómo tras perder una guerra en España y otra en Francia, y con apenas diecisiete años cumplidos, fue apresado por una patrulla alemana e internado en el campo de concentración de Mauthausen. Allí vivió los horrores del nazismo, el envilecimiento extremo del ser humano, las experiencias más crueles del siglo XX. Para Leguineche, la naturaleza humana atesora una maquinaria extraña que tiende a sobrevivir a la mínima oportunidad. Cuenta en El precio del paraíso $(1995,233)$ cómo al ser liberado por las tropas aliadas, Antonio García Barón emigra a la selva de Bolivia, lejos de toda civilización, "con veinticinco pesos en el bolsillo". Allí funda su propia república, basada en la igualdad y en la libertad: la República de Quiquibey. Sus libros, poco a poco, se convierten en lectura indispensable para todo. Es un creador original que no hace relatos de ficción, ni de guerras, sino crónicas creativas y humanas de hombres que no se entienden entre sí. Para Alberto Ojeda, "empezó a hacer Nuevo periodismo antes de que el Nuevo periodismo fuera acuñado por Tom Wolfe, Norman 
Mailer y compañía. Se dio pronto cuenta que había más verdad en las pequeñas cosas que en las grandes, o, lo que es lo mismo, en las vidas anónimas que en los tejemanejes de los altos mandos de los ejércitos, los políticos y los señores de la guerra. Una de sus divisas fue que "los periodistas son gente que le cuenta a la gente lo que le sucede a la gente". Así de simple y así de complicado.

Leguineche empeña su crédito y su esfuerzo en héroes anónimos, y en dar relevancia a quienes luchan por seguir viviendo. Su libro Los ángeles perdidos obtiene el premio Espasa de Ensayo (1996). La materia prima del texto la forman notas tomadas en las guerras y que habían quedado fuera de las crónicas. En él denuncia la explotación de los más pequeños. En 1988 conduce el espacio Memorias en EITB. Una década después, Manu Leguineche graba con Joserra Plaza, reportero de Euskal Telebista, en Peshawar, Afganistán, el documental Verdad Inocente (2001). La idea del documental surge al observar Leguineche a una niña de ocho años que dibuja en un campo de refugiados. Recibe un gran impacto al ver sus hojas, y descubrir que pinta aviones y helicópteros de combate. "Alzó la mirada hacia mí con sus ojos de color negro profundo y me mostró otro dibujo: un talibán pegaba a su madre con un cable eléctrico. La niña se llamaba Hamira y me preguntó: ¿la vida siempre es así?". Leguineche encuentra en sus dibujos "el mejor acta de acusación contra un mundo cada vez más feroz". La mirada de los niños afganos conduce el documental, y una exposición a beneficio de la ONG afgana HAWACA (Ayuda humanitaria para las mujeres y niños).

Su olfato informativo es infalible y la lectura de los hechos siempre inmediata. Joserra Plaza, reportero de ETB, cuenta cómo a los pocos días del 11-S y del atentado a las Torres Gemelas le llama y le dice: "Haz las maletas que nos vamos a Afganistán. Yo estaba en Ruanda, y para allí me fui”. Teniendo en cuenta que Leguineche $(1980,225)$ había estado en Afganistán en repetidas ocasiones, la primera vez cuarenta años antes, podemos decir que para él era lo más normal del mundo. Sabía que volvía otra vez a "un país antiguo con carreteras nuevas" inmunizado al paso del tiempo. La vigencia del diagnóstico de la situación de la mujer, en el Afganistán de 1965, es desolador cincuenta años después: "Aparece también el velo, que aquí se llama chadri, y que oculta por completo a las afganas. Es como una tienda de campaña, como un saco de la cabeza a los pies, con una rejilla abierta a la altura de los ojos. La ley de 1959 abolió el suplicio del chadri, pero las mujeres afganas prefieren no desafiar las estrictas leyes no escritas". Conocen el proverbio local: "apalea a tu esposa y, si se te muere, toma otra," y todo con la bendición de los mullahs".

En los años ochenta también hace televisión y realiza reportajes para Informe Semanal. Siempre con los desfavorecidos, prefiere informar de hambrunas, catástrofes, guerras o magnicidios. Pilar Miró, directora general de TVE, le ofrece la dirección de informativos y la rechaza. Dirige la serie documental En Portada, que se emite durante un año.

Leguineche ya es una autoridad, y graba las entradillas del programa desde su propio despacho. Se mantiene fuera de las grandes componendas del poder mediático, y prefiere renunciar a determinados puestos que hipotecar su independencia. Opta por mantenerse vivo en la profesión, continúa como reportero, su sitio está junto a la noticia y no en los despachos. El asesinato de los jesuitas en El Salvador, entre ellos el del vasco Ignacio Ellacuría; la caída de Ceaucescu en Rumanía o la salida de Bagdad antes de los bombardeos fueron algunos de sus trabajos de mayor impacto. Corresponsal de éxito, y compañero durante un tiempo de la televisiva Rosa María Mateo, ésta le pregunta en una entrevista en directo por la situación más impactante que había vivido.

-Cuando te conocí - responde Manu.

\section{La vitalidad de Manu}

El último periodismo de Manu es coral. Participa en libros colectivos y de conversaciones con los amigos, a quienes obsequia con su tiempo y lucidez en el análisis. Leguineche disfruta del relato vivido, de la anécdota nunca escrita, de la sobremesa de jardín en mangas de camisa y con sombrero panamá. Sus entrevistas son antológicas, llenas de sabiduría en un convulso cambio de siglo. Su mirada sobre la profesión es pesimista. "Cómo está el oficio, Juanito", le dice a Juan Cruz en una entrevista para El País. A finales de los noventa ya se dejaba ver menos por la redacción. Pilar Cernuda destaca, desde siempre, su "facilidad para crear equipos, su empeño en defender a su gente, su capacidad para tener amigos en los sectores más pintorescos excepto en 
los que se mueven en los grandes salones, su aversión por los fastos y su afán por participar en cualquier festejo popular y pintoresco, su acusada tendencia a cantar Granada cuando bebía una copa de más, siempre tinto con sifón o tinto solo si era bueno, su amor por la Fallaci -incomprensible porque era insoportable- y su visión para saber dónde se producía la noticia".

Durante años obtiene un caluroso feddback de tantos años de generoso esfuerzo. Pilar Bernal recuerda lo que llama los momentos Manu. Sus apariciones por la agencia LID eran escasas, pero estelares. "Un día trajo paella para toda la redacción y empezó a departir sobre la actualidad mundial, lo mismo disertaba acerca del curso de la guerra del Congo o sobre la muerte de Lady Di y su escandaloso romance con Dodi. En otra ocasión trajo una caja llena de gatitos y nos invitó adoptar uno. Yo salí de allí con mi primera mascota: Parry Mason nacido de los pechos de Leguineche". Durante la grabación de Oxigeno para vivir, el fotorreportero Enrique Meneses visita a Leguineche. Su gata busca abrigo en el amigo. Me ha adoptado dice Enrique. "Tengo muchos gatos para que tengan muchas vidas", le responde Leguineche. Antonio Pérez-Henares cuenta cómo le llamó Manu desde Belgrado, donde iba a bombardear la OTAN, para que fuera a casa de Morales a recoger dos perros que habían ganado jugando al mus. No le pregunté cómo se había enterado desde Belgrado que había parido la perra de Enrique. Desde entonces, y durante dieciséis años, estuvimos emparentados por parte de mi perro Lord.

Poco a poco la enfermedad va dejando fuera de juego a un tipo arrollador, singular, superlativo, trabajador, hiperactivo, que ha vivido el periodismo en blanco y negro de las viejas rotativas. Se refugia en la conversación, el mus o en su Athletic de toda la vida. Iriondo, Venancio, Zarra, Panizo y Gaínza eran los cinco magníficos, la mejor delantera de la historia del club. Manu estaba marcado por el "cromosoma del Athletic", y en su libro Conversaciones en la Catedral (1998) comenta con Patxo Unzueta y Santi Segurola las más increíbles anécdotas de los seguidores rojiblancos. Explica desde algunas experiencias vividas al límite cómo hay sentimientos de los que sólo se toma conciencia con el tiempo y desde la distancia. Cita muchos sucedidos, y disfruta al imaginar a los teólogos de la liberación Jon Sobrino e Ignacio Ellacuría refugiándose en un campanario en medio de un tiroteo, con un pequeño transistor, y siguiendo al Athletic de Clemente: "No todo está perdido, acaba de marcar Noriega".

Dice Santi Segurola: "dime tu jugador favorito y te diré cómo eres". Rafa Iriondo $(2013,148)$ era el futbolista de Leguineche. También de Gernika y superviviente de una infancia en la guerra civil, jugaba de extremo derecha, pegado a la frontera de la banda, sirviendo balones a la cabeza del mítico Telmo Zarra, "después de Churchill, la mejor cabeza de Europa”. Iriondo llegó a marcar 115 goles con el Athletic, ganó cuatro copas y una liga. Michael Herr, autor de Despachos de Guerra, ya quien trató en Saigón durante la Guerra de Vietnam, solía decir: "No hemos tenido infancias felices, pero hemos tenido Vietnam". Leguineche usaba la cita a menudo y la versionaba a su manera: "quizá no tuvimos infancias felices, pero tuvimos Athletic. Superamos el trago a base de libros, cine y Athletic. Hemos cambiado de señora, o nos ha cambiado ella, de periódico, de cepillo de dientes, de partido, de amigo, de coche, de marca de whisky, de desodorante, pero no de Athletic".

El siempre jovial presentador Ramón García cuenta cómo cada vez que coincidían en TVE su saludo era siempre el mismo: ¡hombre, otro del Athletic!, y eso que no es fácil superar a Ramontxu en entusiasmo. Santi Segurola explica su vitalidad: "Manu evitaba la solemnidad y procuraba el disfrute. Alcanzó todos los rincones del planeta pertrechado con un entusiasmo y una fe indescriptibles en el rédito social del periodismo". La ilusión y la emoción son, por tanto, consustanciales a su forma de entender la vida y el periodismo.

Finalmente encuentra descanso en La Alcarria, en Brihuega, a la vera de la mejor miel, un buen vino y una baraja española. El gusto por el idioma y la expresión le lleva a reivindicar el mus, además de como un juego, como una actitud ante el destino y la adversidad. Sobre este particular, el dibujante y académico Antonio Mingote $(2008,91)$ afirma: "El juego del mus tiene un lenguaje propio, constituido por palabras, frases y conceptos cuyo sentido sólo conocen los iniciados. Este lenguaje que se ha ido formando a través de generaciones de ingeniosos, se enriquece día a día con nuevos modismos, mientras otros caen en desuso". Su fin primordial consiste en reírse los jugadores unos de otros y pasar un buen rato sin grandes apuestas. "Quien al mus juega ceñudo su mujer le hará cornudo", reza el aforismo y la alegría vital forma parte intrínseca del juego, como explica Mingote: $(2008,17)$ "no se puede considerar al fulano sombrón como jugador de mus, sino como un pelmazo que lo que tendría que hacer es dedicarse a la explotación de hidrocarburos, a la 
compraventa de fincas manifiestamente mejorables y cosas así". Don Juan Carlos de Borbón escribe el prólogo del libro La ley del mus (1992), y Leguineche recurre a Unamuno en Mus visto $(2000,14)$ para destacar la voz órdago como genuina aportación vasca al castellano. "Órdago, ahí está mi alma", suscribe Leguineche, eso sí, lejos de las agonías de Don Miguel.

La apuesta forma parte de su ADN. Cierto día se hizo una consigo mismo: dar la vuelta al mundo en menos días que Julio Verne. Lo contó en La vuelta al mundo en 81 días (1998), lo intentó y no lo logró. "Esa mano era de Verne". Sus muchas experiencias confirman que "los peores viajes dejan los mejores libros" y que, como es sabido, "una partida no está perdida hasta que está ganada". En los últimos años, su vitalidad adquiere un tono nostálgico. Cultiva la vida contemplativa que se ha organizado en su retiro alcarreño. Cuenta Belén Ayala que con Manu aprendió también que "no todo era tan romántico. Muchas veces sufría, pero era como la vida misma: unas veces arriba y otras quitándote el barro de la cara después del último revolcón. Siempre estuvo ahí, quejoso de lo duro que era todo pero sin maldecir su enfermedad. Era su forma de entender la profesión y de vivir la vida". Acompañado de sus hermanos Rosa y Benigno, recibe a los amigos en su "Casa de los Gramáticos" de Brihuega, en la que escribe La felicidad de la tierra (2001), una pequeña joya, un tratado de vida de amor hacia lo elemental y la emoción del instante. Se siente atrapado en la épica de la melancolía, desplazado por no poder desplazarse. Da con algunas fórmulas un tanto agridulces como El club de los faltos de cariño (2007). Mantiene en su mochila los sabores de su infancia, y no faltan en su casa los pimientos y alubias de Gernika. Como recuerda Txato Etxaniz, del grupo de historia Gernikazarra, fue el autor del lema Gernika, Guernicara con el que se reivindicó durante años la exposición del mural de Picasso en Bizkaia. En su casa de Brihuega había plantado un retoño del Árbol de Gernika. "Soy fuerte y débil. A veces me voy para estar más cerca de mí, y eso mismo me pasa con mi propio país".

En ocasiones también se fuga de La Alcarria. Cuando aprieta el frío se escapa a Garrucha, en Almería. Sale al mar con Javier Reverte y otros amigos. Comparten guisos marineros en las tabernas del puerto y cuando pierde un órdago al mus, discute a "cara de perro" el mejor descarte. El editor Eduardo Riestra cuenta una comida inolvidable a tres bandas: "Javier Reverte llevó medio kilo de caviar conseguido de estraperlo, el que esto escribe una caja de percebes del Roncudo y Manu Leguineche puso la casa y el champán. Y brindamos por el Lúculo de Julio Camba".

Separados durante mucho tiempo, Miguel Delibes y Manu Leguineche se encuentran ambos convalecientes y cada uno retirado en su propia casa. El discípulo saluda y elogia al maestro a través de los micrófonos de Radio Nacional. El 12 de abril de 2007, Miguel Delibes envía una pregunta través de un amigo común que entrevista a Leguineche:

-"Querido Manu, ¿no crees que con el humanismo que rezuman tus personajes, combatientes o no, y la sensibilidad y el afán de vivir que muestran los seres que creas, tú debiste ser llamado corresponsal de paz y no de guerra? Yo así lo entiendo..."

- Le respondería a Miguel que no puedo por menos de estar de acuerdo con él. Porque ese era mi propósito, aunque no lo anunciara, ¿no? Mi propósito era ser corresponsal de paz. Bien es verdad que como luego da lo mismo lo que hagas, pues la verdad es que tienen muy poca fuerza tus argumentos. Pero así es como dice Miguel. Y a algún rincón perdido habrá llegado mi mensaje. Pero vamos, es que es la primera vez que me ocurre una cosa tan bonita como ésta de contestar a una pregunta de Miguel".

\section{La huella de Leguineche}

En las páginas de El Mundo, Gallego \& Rey publican una tira: "A Manu en el recuerdo". Un periodista corre con su libreta y su bolígrafo, huye del fuego enemigo. Salta a una trinchera. En un picado se ve que el foso es la inmensa pisada que ha dejado Leguineche como corresponsal de guerra y que salva al reportero. La huella de Leguineche tiene el valor de un refugio ético y afectivo al que acudir cuando las cosas se ponen feas. Todos lo saben. A su muerte, la unanimidad es tan absoluta como inusual en un mundo tan desabrido como el periodismo actual. "Era el mejor periodista porque era la mejor persona", dice su amigo Antonio Pérez-Henares. Todos destacan su compañerismo y la estela de su recuerdo se nutre de las vivencias más personales. La tribu de corresponsales despide a su gran jefe y la profesión a un maestro de periodistas, todos destacan su 
bonhomía y profesionalidad.

Las grandes cabeceras llevan a portada el fallecimiento de Manu Leguineche "Adiós a un grande del periodismo", titula El País; "Adiós a Manu Leguineche, el gran jefe de la tribu", destaca El Mundo bajo su cabecera del 23 de enero y, en interiores, "La tribu se queda huérfana"; también la prensa regional: "Fallece el maestro de periodistas Manu Leguineche. Reportero de guerra, columnista y escritor, estaba considerado como un adalid de la independencia", publica en portada El Progreso. Enrique de Ybarra, presidente de Vocento, firma los diarios de su grupo: "Manu ha dejado un legado documental de primer orden, tanto en sus libros como en sus reportajes, es una referencia para las nuevas generaciones y un maestro para mí como periodista. Trabajé a sus órdenes durante seis años en Madrid al término de mis estudios de Derecho. Me enseñó el valor de la independencia en esta profesión y el amor al trabajo bien hecho. Era inteligente y bueno, y transmitía la pasión por el oficio, respetando siempre la capacidad de respuesta del lector. Sus libros eran un compendio de gozo de vivir y de conocimiento de uno mismo a través de sus viajes". Todos los periódicos destacan la, no por esperada, menos triste noticia.

Las voces más importantes de la radio también le dedican sus comentarios más elogiosos. Carlos Herrera hace un encendido homenaje de su figura en Onda Cero. Iñaki Gabilondo habla de "nuestro Kapuscinski" y la unanimidad en las ondas es total. La reconocida corresponsal de televisión Rosa María Calaf y Pepa Bueno hablan en la cadena SER sobre el saber hacer de "un reportero que desde la modestia siempre está al servicio de la noticia, tratando de explicar por qué suceden las cosas, además de lo que pasa en ese momento". En la redes se produce un gran aluvión de tuits, que convierten la noticia de su muerte en trending topic a los pocos minutos de conocerse la noticia. Twitter alcanza siete millones de impactos, todos los periodistas quieren dejar su pequeño homenaje, entre ellos el de Ramón Lobo, corresponsal de guerra, que destaca: "el ejemplo de una vida llena de coraje". Como suele pasar con estas noticias, un año antes ya había corrido el bulo de su muerte. En las redes sociales se había producido el mismo efecto, un espectáculo gozoso del que pudo disfrutar Manu desde su retiro en Brihuega, sabedor de que "Ios viejos musistas nunca mueren y, si lo hacen, porque no queda más remedio, en el cementerio y en el cielo juegan al mus".

Jesús Maraña, director de InfoLibre, en una conferencia en el teatro Cánovas de Málaga señala que "la principal misión del periodista, como lo hacía Leguineche, es ser testigo de lo que está pasando y trasladarlo al resto de la gente". En las tertulias, de todos los palos, siempre hay un amigo del reportero que cuenta alguna anécdota; el resto de los participantes dicen que siempre se han informado de los acontecimientos mundiales a través de su mirada. La televisión recupera sus imágenes de archivo y Estíbaliz Ezquerra, crítica de Gara, contrasta "el halo de inmortalidad" que envuelve al hombre del bigote en el recuerdo de los espectadores. Sus grandes gafas cuadradas, como las teles de la época, vuelven a las pantallas de plasma y certifican la presencia de Leguineche en los momentos decisivos de las últimas décadas siglo XX. Ignacio Escolar cuelga en Facebook y en eldiario.es la conversación entre Manu Leguineche, Amalia Sanpedro y Enrique Meneses del documental Oxigeno para vivir de Georgina Cisquella. Hablan de la tribu, de la crisis de la profesión y de la pérdida del sentido de la aventura. "Piérdete si quieres", recuerdan del lanzamiento publicitario del primer GPS de Sony. Los guionistas de la serie Cuéntame cómo pasó (5/5/2014)incluyen citas de Leguineche como referencia de autoridad en sus diálogos periodísticos.

Su trayectoria es reconocida con numerosos y prestigiosos galardones: Nacional de Periodismo (1980), Cirilo Rodríguez (1984), Julio Camba (1991), Ortega y Gasset (1991), Espasa de Ensayo (1996), la medalla de la Orden al Mérito Constitucional (1997), Periodista Vasco de la Asociación de Periodistas Vascos (2007), FAPE de Periodismo (2007), Ilustre de Bizkaia (2008), Reporteros de El Mundo (2008) Agustín Merello (2009), Luca de Tena (2010) y el "Premio Gernika por la paz y la reconciliación" (2014), junto al oficial británico John Wynne. También recibe reconocimientos populares, como Su Peso en Miel (2004), la Pluma de Oro en la feria del libro de Bilbao, o su nombramiento como hijo adoptivo de Castilla-La Mancha. En 2008 es propuesta su candidatura al premio Príncipe de Asturias de Comunicación y Humanidades. El jurado opta por entregárselo a Google, signo de los tiempos y del cambio de valores. Una lucha desigual y que todavía atormenta a algunos, como a su amigo Alfonso Rojo: "No hemos sido justos con el viejo maestro".

La revolución digital termina por convertir a Leguineche en un viejo maestro de la galaxia Gutenberg, un ilustre faraón en su pirámide de papel prensa. Él era consciente del cambio imparable en la profesión. En 1992 cuando 
recibe el Premio Ortega y Gasset, dice en su intervención: "debemos aprender a ajustar el tiro, la televisión en directo lo ha trastornado todo... ¿Para qué repetir lo que ya se ha visto por la CNN? Cada vez pasan más siglos entre la retrasmisión de la CNN y tu artículo en el periódico, y no digamos en la revista. Hay que decir adiós a la narración escenográfica de los hechos, escudriñar allí donde los objetivos de la televisión no llegan, descubrir antecedentes y consecuentes, atmósferas y ambientes secretos". Hoy en día la situación ha llegado mucho más lejos y, cómo señala Jesús Maraña, son los propios ciudadanos quienes tienen esa función en sus manos. "El ciudadano es tan partícipe del periodismo que puede empezar a enviar mensajes diciendo que helicópteros están sobrevolando su casa, están disparando, están aterrizando...y media hora después se conoce que esa persona estaba informando de la muerte de Bin Laden". Leguineche sabía que habían cambiado las témporas para el periodismo y, como escribe José Miguel Giráldez, "lo peor no es que sean malos tiempos para el periodismo, sino malos tiempos para aquél periodismo".

Para Mariano Guindal, "Manu probablemente haya sido el periodista más brillante de su generación. Un corresponsal de guerra excepcional. Un gran escritor”. Con muy pocos recursos es capaz crear grandes equipos, una demostración práctica durante años de lo que ahora se reconoce como inteligencia colectiva: "con cuatro manzanas somos capaces de hacer un banquete medieval". Antonio Pérez destaca que todo el mundo hablaba bien de él. Rara unanimidad. Su enseñanza es cristalina: "un reportero tiene que ir y contar las cosas. Él las contaba como las veía, trataba de llegar al fondo. Y también dar voz a los que no la tienen. Eso es el periodismo: el intento de veracidad, aunque sea la subjetiva de cada uno". Para él, hablar con personas anónimas proporcionaba más información que pisar las moquetas del poder, y entre sus consejos a los más jóvenes citaba siempre la necesidad de mantener siempre la curiosidad y leer los periódicos.

Evaristo Canete, a través de su gran angular, ve al amigo y al maestro. "Coincidí con Manu en Ruanda, Argentina, Filipinas, Hong Kong..., y era alguien del que siempre podías aprender. Yo era cámara, Manu era mucho más, pero eso no impedía ser consciente de que a su lado, uno era mejor. Era vasco, muy vasco. Si te encontrabas con él, te ayudaba en todo lo que necesitaras. Pero a pesar de ello, el jefe de la tribu se las arreglaba solo. Sabía y podía hacerlo. Su trabajo le convierte en un maestro del reporterismo español y un referente en el periodismo mundial". Nada más conocerse la noticia de su muerte, los columnistas ya le echaban de menos. David Trueba deja una última lágrima en su columna La Guerra de Hoy (por la de Siria). "Todo este tiempo sólo ha servido para prolongar la indecencia criminal de esta guerra que mata como las de antes a los de siempre, pese a la retransmisión diaria y global. Y sin Manu Leguineche para contarla”. Así son dos.

\section{Conclusiones: el canon del corresponsal internacional}

Algo tendrá el agua cuando la bendicen, después de estudiar el perfil de un reportero tan reconocido dentro de la profesión, y fuera de ella, como Manu Leguineche, tal vez se puedan establecer algunas de las virtudes que atesora como canon del corresponsal internacional. Cualidades vinculadas al carácter o la propia personalidad de quien ejerce esta profesión, como la curiosidad, o la audacia, para interesarse por los acontecimientos que afectan a la vida de los protagonistas y a su entorno.

El interés por observar y comparar con otras situaciones, vividas o descritas por otros, para llegar a leer y ver más allá de lo evidente. La afición a las paradojas y al detalle inesperado, que dan color a las historias y permiten empatizar con los protagonistas y convertir su relato en novedad para el lector. El gusto por la noticia, la diferencia, el contexto y el conocimiento profundo de las cosas. La capacidad de síntesis para condensar el despacho de agencia, y a su vez, una percepción y una memoria de las sensaciones que permiten desarrollar en crónicas, libros y reportajes acontecimientos más complejos tratando de explicar las causas y consecuencias de los acontecimientos.

Otra de las características es, sin duda, la extraordinaria movilidad, la disposición y velocidad para viajar ligero de equipaje, aunque sea con un equipo de televisión a cuestas. La empatía para asimilar y entender el dolor ajeno, para trasladar una verdad que en muchas ocasiones solo es un grito desesperado de los más débiles. La objetividad para no perder la noción de lo que realmente sucede frente a las querencias del reportero.

La ironía y el humor también ayudan a sobrellevar una vida difícil de conciliar con una rutina familiar al uso. "El 
desorden es el orden de cada uno", decía Luis Carandell y Manu Leguineche también tenía el suyo. La intuición para seleccionar y organizar equipos, para distribuir tareas y recursos en entornos complejos y dinámicos. El gusto por el idioma, por la expresión y las voces originales. La sensibilidad para leer la actualidad, llegar con el rumor y salir con la noticia. En definitiva, tener el valor y los reflejos para estar en el lugar de los hechos, y la pericia, y el saber para contarlo a través de cualquier medio o soporte técnico. Y, también, algo de fe en el periodismo, en la capacidad de las palabras y de las imágenes para cambiar las cosas.

\section{Bibliografía}

DELIBES, Miguel (2007) Obras Completas VI: El periodista. El Ensayista. "A Manuel Leguineche" en Galaxia Gutenberg-Círculo de Lectores, Barcelona

DELIBES, Miguel y DELIBES DE CASTRO, Miguel (2007) La Tierra herida. Destino, Barcelona.

GABILONDO, Iñaki. (2011) El fin de una época. Barril \& Barral. Barcelona.

GUINDAL, Mariano. (2011) El declive de los dioses. Planeta. Barcelona.

HEMINGWAY, Ernest. (1967): París era una fiesta. Seix Barral. Barcelona (2003). Prólogo de Manuel LEGUINECHE.

HEMINGWAY, Ernest. (1968): Enviado especial. Planeta. Barcelona.

LEGUINECHE, Manuel y TORBADO, Jesús (1977): Los topos. Argos Vergara. Barcelona.

LEGUINECHE, Manuel. (1978): El camino más corto. Argos Vergara. Barcelona.

LEGUINECHE, Manuel. (1988): La vuelta al mundo en 81 días. Ediciones B. Barcelona.

LEGUINECHE, Manuel. (1989): Filipinas es mi jardín. Ediciones B. Barcelona.

LEGUINECHE, Manuel. (1996): Los ángeles perdidos. La explotación del niño en el mundo. Espasa. Madrid.

LEGUINECHE, Manuel. (1997): El precio del paraíso "de un campo de exterminio al Amazonas" Espasa Calpe, Madrid.

LEGUINECHE, Manuel. (1998): Yo te diré...La verdadera historia de los últimos de Filipinas. El País-Aguilar. Madrid.

LEGUINECHE, Manuel, UNZUETA, Patxo y SEGUROLA, Santiago. (1998): Athletic 100. Conversaciones en La Catedral, Aguilar. Madrid.

LEGUINECHE, Manuel. (1998): “Yo pondré la guerra”. Cuba: 1898: la primera guerra que se inventó la prensa.

El País-Aguilar. Madrid.

LEGUINECHE, Manuel. (1999): Hotel Nirvana. La vuelta Europa por los hoteles míticos y sus historias. El PaísAguilar. Madrid.

LEGUINECHE, Manuel. (1999): Madre Volga. Alfaguara. Madrid.

LEGUINECHE, Manuel. (1999): La felicidad de la tierra. Alfaguara. Madrid.

LEGUINECHE, Manuel y MARTíN de ARELLANO, Lalo. (2000): Mus visto. Plaza \& Janés. Madrid.

LEGUINECHE, Manuel y SÁNCHEZ, Gervasio (2001). Los ojos de la guerra. "Sin novedades en el frente". Plaza \& Janés, Barcelona.

LEGUINECHE, Manuel y PLAZA, Joserra (2001): Verdad Inocente. Documental ETB y Exposición Sala Rekalde, Bilbao. 
LEGUINECHE, Manuel. (2002): Gibraltar. Planeta. Barcelona.

LEGUINECHE, Manuel. (2004): El último explorador: la vida del legendario Wilfred Thesiger. Seix Barral, Barcelona.

LEGUINECHE, Manuel. (2007): El club de los faltos de cariño. Seix Barral, Barcelona.

LEGUINECHE, Manuel y TORBADO, Jesús (2010): Los topos. Capitán Swing. Madrid.

MÉNDEZ, Alberto: (2004). Los girasoles ciegos. Anagrama, Barcelona.

MINGOTE, Antonio. (2008): El mus. Maeva, Madrid.

PÉREZ REVERTE, Arturo: (1994). Territorio Comanche. Ollero \& Ramos. Madrid.

REVERTE, Javier. (2000) Billete de ida. Aguilar, Madrid.

RODRIGÁLVAREZ, Eduardo. (2013). Historias de San Mamés. Ttarttalo, Donostia.

ROSENDO de, Belén. (2010). El perfil periodístico. Claves para caracterizar personas en prensa, Tecnos, Madrid.

\section{Hemerografía}

ALTARES, Guillermo. "Muere el periodista y escritor Manu Leguineche” en El País, 22/1/2014.

ARREGI, Juan Mari. “Leguineche apostó por Egin”, en Gara, 24/1/2014.

ASTUY, Iratxe y ESTEBAN, Iñaki. “El aldeano trotamundos” en El Correo, 23/1/2014.

AYALA, Belén. "Manu fue mi maestro", en El País, 22/1/2014.

BAULUZ, Alfonso. "Javier Espinosa, inquieto y locuaz reportero en la estela de Manu Leguineche”, EFE, $30 / 3 / 2014$.

BERNAL, Pilar. “Manu Leguineche, jadiós al jefe!”, en El mundo desde mi tele, 26/2/2014.

CANETE, Evaristo. “Un ejemplo para todos”, en El Mundo, 23/1/2014.

CERNUDA, Pilar. “Manu” en El Progreso, 23/1/2014.

CISQUELLA, Georgina. “Oxígeno para vivir. Periodismo de la generación Magnum a la 2.0” Doc, 31/1/2011.

CLEMENTE, Enrique. "El jefe de la tribu”, en La Voz de Galicia, 23/1/2014.

CONDE, Raúl. "La "tribu” se queda huérfana”, en El Mundo, 23/1/2014.

CRUZ, Juan. "La felicidad de Manu" en El País, 22/1/2014.

ESCOLAR, Ignacio. "Manu Leguineche y Enrique Meneses hablan sobre periodismo" en eldiario.es y Facebook.com, 24/1/2014.

EZKERRA, Estibaliz. “Manu Leguineche y el oficio de reportero de guerra” en Gara, 22/1/2014.

FERNÁNDEZ BARRERA, Javier. “Lecciones de periodismo que nos enseñó Manu Leguineche”, en 1001 medios.es, 23/1/2014.

FOCES, J.I. “El día que Delibes entrevistó a Leguineche”, en El Norte de Castilla, 23/1/2014

FRAGA, Xesús. "Muere Manu Laguineche, cronista de las guerras de final del siglo XX”, en La Voz de Galicia, 23/1/2014. 
GARCIA, Aitzol. “Y con él se rompió el molde”, en Deia, 23/1/2014.

GALLEGO \& REY. "A Manu en el recuerdo" en El Mundo, 23/1/2014.

GIRÁLDEZ, José Miguel. "El jefe de la tribu”, en El Correo Gallego, 23/1/2014.

GUINDAL, Mariano. “Llanto por mi maestro Manu Leguineche”, en El Confidencial, 23/1/2014.

GUINDAL, Mariano. "Tributo a Manu Leguineche. Muerte de un periodista”, en El Boletín.com, 15/2/2014.

JIMÉNEZ, Irene. "Muere el reconocido reportero de guerra "Manu" Leguineche", en El Correo Gallego, 23/1/2014.

LEGUINECHE, Manuel. “Portugal en calma”, en La Nueva España, 24/4/1999.

LEGUINECHE, Manuel. "Érase una vez La Alcarria”, en El País, 8/8/2002.

LEGUINECHE, Manuel. "El periodista que vino del telón de acero”, en El País, 25/1/2007

LEGUINECHE, Manuel. "Disculpas (inútiles) de Lula”, en El Correo, 25/8/2005.

LUSSÓN, Fernando. "Manu, periodista de agencia”, en El Correo Gallego, 23/1/2014.

MARAÑA, Félix. "Manu temperatura del mundo", en El Correo, 23/1/2014.

MARAÑA, Jesús. “La función del periodista ha cambiado", en InfoLibre.es, 24/1/2014.

MORÁN, Gregorio. "Mensaje en una botella”, en La Vanguardia, 13/11/2010.

MÚGICA, Fernando. "Te daré un beso", en El Mundo, 23/1/2014.

M.I. "Manu Leguineche, el Marco Polo del periodismo", en ABC.es, 22/1/2014.

NIETO, Marta. "El ojo inocente de la guerra" en El País, 20/12/2001

ONETO, José. "En la muerte de Manu Leguineche" en República.com de las ideas 22/1/2014.

OJEDA, Alberto. "Muere Manu Leguineche, el patriarca de la "tribu" en El Cultural, 22/1/2014.

PANIAGUA, Antonio. "Adiós a un periodista curtido en mil batallas" en El Correo, 23/1/2014.

PÉREZ-HENARES, Antonio. "Era el mejor periodista porque era la mejor persona", en Periodista Digital, $22 / 1 / 2014$.

PORTOCARRERO, Enrique. “Oficio y corazón” en El Correo, 23/1/2014.

RIESTRA, Eduardo. "Órdago a la grande”, en La Voz de Galicia, 23/1/2014.

ROJAS, Alberto. "Maestro de la crónica, reportero de leyenda", en El Mundo, 23/1/2014.

ROJO, Alfonso. "Tengo una enorme deuda con Manu Leguineche y se ha ido sin que se la pagara", en Periodista Digital, 23/1/2014.

SÁNCHEZ, Gervasio. “Uno de los mejores”, en El Mundo, 23/1/2014.

SEGUROLA, Santiago. “Leguineche y el cromosoma del Athletic” en El Mundo, 23/1/2014.

TORRADO, Jesús. "Travesías compartidas” en El País, 22/1/2014.

TRUEBA, David. “Guerra de hoy” en El País, 23/1/2014. 
VEIGA, Pilar. R. "Fallece Manu Leguineche, el maestro de periodistas" en El Progreso y Diario de Pontevedra, 23/1/2014.

\section{Bibliografía propia de Manuel Leguineche}

LEGUINECHE, Manuel. (1965): Actor y general. Edebe, Barcelona.

LEGUINECHE, Manuel. (1972): Raphael. Dopesa Barcelona.

LEGUINECHE, Manuel y otros (1973): Díez-Alegría: jesuita prohibido. Fundamentos. Madrid.

LEGUINECHE, Manuel y SOLAR, David (1975): Los Palestinos atacan: de Monte Scopus 1948 a Madrid 1975.Felmar-PuntoCrítico, Madrid.

LEGUINECHE, Manuel: (1976) Portugal, la revolución rota. Felmar-Punto Crítico, Madrid.

LEGUINECHE, Manuel y TORBADO, Jesús (1977): Los topos. Argos Vergara. Barcelona.

LEGUINECHE, Manuel. (1978): El camino más corto. Una trepidante vuelta al mundo en automóvil. Argos Vergara. Barcelona.

LEGUINECHE, Manuel. (1981): La tribu. Argos Vergara. Barcelona.

LEGUINECHE, Manuel. (1982): El estado del golpe. El golpismo en Europa: Gracia, Italia, Turquía, Francia, Gran Bretaña, Polonia...y España. Argos Vergara. Barcelona.

LEGUINECHE, Manuel. (1982): Los grandes hechos del siglo XX. Orbis, Barcelona.

LEGUINECHE, Manuel. (1983): La destrucción de Gandhi. Editorial JAB. Barcelona.

LEGUINECHE, Manuel. (1985): Sobre el volcán. Una aventura desde Guatemala Panamá a través del Salvador, Honduras, Nicaragua y Costa Rica. Plaza y Janés. Barcelona.

LEGUINECHE, Manuel. (1985): La guerra de todos nosotros. Vietnam y Camboya (1948-1985). Plaza y Janés Barcelona.

LEGUINECHE, Manuel. (1988): La vuelta al mundo en 81 días. Ediciones B. Barcelona.

LEGUINECHE, Manuel. (1989): Filipinas es mi jardín. Ediciones B. Barcelona.

LEGUINECHE, Manuel. (1990): La primavera del Este: 1917-1990, la caída del comunismo en la otra Europa. Plaza y Janés. Barcelona.

LEGUINECHE, Manuel y otros. (1990): Uganda. Manantial de África. Agencia Española de Cooperación Internacional-Sirecox. Madrid.

LEGUINECHE, Manuel. (1992): La ley del mus. Ediciones del Prado. Un juego llamado mus. Edición de lujo. Madrid

LEGUINECHE, Manuel. (1992): En el nombre de Dios: el Islam militante, los árabes, las guerras del Golfo. Plaza y Janés-Cambio 16. Barcelona.

LEGUINECHE, Manuel. (1992): Yugoslavia kaputt. Ediciones B. Barcelona.

LEGUINECHE, Manuel. (1993): Apocalipsis Mao. Espasa Calpe. Madrid.

LEGUINECHE, Manuel. (1995): Los años de la infamia: Crónica de la l/ Guerra Mundial. Círculo de Lectores. Barcelona.

LEGUINECHE, Manuel, DELIBES, Miguel y LUJÁN, Néstor. (1995): 25años de escopeta y pluma. 
LEGUINECHE, Manuel. (1996): Los ángeles perdidos. La explotación del niño en el mundo. Espasa. Madrid.

LEGUINECHE, Manuel y VELASCO, María Antonia. (1996): El viaje prodigioso: 900 años de la primera cruzada. Alfaguara. Madrid.

LEGUINECHE, Manuel. (1997): El precio del paraíso "de un campo de exterminio al Amazonas" Espasa Calpe, Madrid.

LEGUINECHE, Manuel. (1997): Adiós, Hong Kong. Plaza y Janés. Barcelona.

LEGUINECHE, Manuel. (1998): Yo te diré...La verdadera historia de los últimos de Filipinas. El País-Aguilar. Madrid.

LEGUINECHE, Manuel, UNZUETA, Patxo y SEGUROLA, Santiago. (1998): Athletic 100. Conversaciones en La Catedral, Aguilar. Madrid.

LEGUINECHE, Manuel. (1998): “Yo pondré la guerra”. Cuba: 1898: la primera guerra que se inventó la prensa. El País-Aguilar. Madrid.

LEGUINECHE, Manuel y TORRES, Maruja. (1999): Introducción a Javier Bauluz: Sombras en combate. Turkana, Madrid.

LEGUINECHE, Manuel. (1999): Hotel Nirvana. La vuelta Europa por los hoteles míticos y sus historias. El PaísAguilar. Madrid.

LEGUINECHE, Manuel. (1999): La felicidad de la tierra. Alfaguara. Madrid.

LEGUINECHE, Manuel y MARTÍN de ARELLANO, Lalo. (2000): Mus visto. Sólo para los que saben juga (muy bien) al mus. Plaza \& Janés. Barcelona

LEGUINECHE, Manuel y otros (2000): 30 años con trofeo. “Guerra, pelo y pluma” América lbérica, Madrid.

LEGUINECHE, Manuel. (2000): Belice. Fotografía de Joan COSTA. Agencia Española de Cooperación Internacional, Madrid

LEGUINECHE, Manuel (2000): Brasil, el hombre que veía demasiado. Lunwerg Editores, Barcelona.

LEGUINECHE, Manuel (2000): La tierra de Oz: Australia vista desde Darwin hasta Sidney. Aguilar. Madrid.

LEGUINECHE, Manuel. (2001). Recordad Pearl Harbour. Temas de Hoy. Madrid.

LEGUINECHE, Manuel y SÁNCHEZ, Gervasio (2001): Los ojos de la guerra. Plaza \& Janés, Barcelona.

LEGUINECHE, Manuel. (2001). "Sin novedades en el frente” en VVAA. (2001): Los ojos de la guerra. Plaza \& Janés, Barcelona.

LEGUINECHE, Manuel. (2001). Recordad Manhattan: el 11 de septiembre, Afganistán la guerra. Temas de Hoy. Madrid.

LEGUINECHE, Manuel y REVERTE, Javier. (2001): El diente de la Bayena. (Prólogos) Punto de lectura. Madrid.

LEGUINECHE, Manuel. (2002): Gibraltar. Planeta. Barcelona.

LEGUINECHE, Manuel y otros. (2002): Día de la infamia. El análisis y reflexiones del 11-S. Esfera de los libros. Madrid.

LEGUINECHE, Manuel y otros. (2003): La letra de los ríos. “Teoría del Tajo” Diputación de Guadalajara-Maorí. Guadalajara. 
LEGUINECHE, Manuel. (2004): El último explorador: la vida del legendario Wilfred Thesiger. Seix Barral, Barcelona.

LEGUINECHE, Manuel. (2003): Madre Volga. Seix Barral. Barcelona.

LEGUINECHE, Manuel. (2007): El club de los faltos de cariño. Seix Barral, Barcelona.

LEGUINECHE, Manuel y otros. (2012): Grandes pasiones de la Historia. El País. Madrid.

LEGUINECHE, Manuel y otros. (2012): Exilio. La historia olvidada. El País. Madrid

\section{Breve semblanza del autor:}

Fermín Galindo Arranz es Profesor Titular de Periodismo en el Departamento de Ciencias de Comunicación de la Universidad de Santiago de Compostela y autor del libro Julio Camba: unha lección de xornalismo (Ediciones Lea, 2002) y de otros trabajos sobre el periodismo cambiano.

Ámbitos. Revista Internacional de Comunicación, n.26, año 2014, tercer trimestre (otoño).

Recibido: 22/5/2014

Aprobado: 5/10/2014 